Website: https://ojs.unikom.ac.id/index.php/common

DOI Jurnal: https://doi.org/10.34010/common

DOI Artikel: https://doi.org/10.34010/common.v3i2.1685

\title{
PENGARUH PRODUCT PLACEMENT TERHADAP BRAND AWARENESS “MIE SEDAAP CUP” FILM “CINTA BRONTOSAURUS" DI KALANGAN REMAJA SURAKARTA
}

\author{
Oktaviani Wahyu Widayanti \\ Jurusan Ilmu Komunikasi Fakultas Komunikasi dan Informatika Universitas Muhammadiyah \\ Surakarta, Jl. A Yani Tromol Pos I Pabelan Kartasura, Surakarta 57102, Indonesia
}

\author{
E-Mail: \\ oktaviaww101@gmail.com
}

\begin{abstract}
Community decisions in selecting the brand supported from its brand awareness factors, public awareness of the brand is driven by the presence of a stimulus that is done by the manufacturer so as to make consumers interested in the product. The film was considered could be a container for the producers to give stimulus as well as market and introduce its products. Use product placement manufacturer to market a brand which is inserted in a piece of film. The intensity of exposure to product placement to the impressions of the audience considered may affect the level of brand awareness of a product, so that it can improve the image of a brand's products and, can directly improve the marketability of the product. The purpose of this research is to know the influence of exposure to product placement in the film against the brand awareness of a product. The research method used is the study of quantitative experiments. The population of this research was a teenager from among the students communication studies Muhammadiyah University of Surakarta. The results of the research with data correlation of cultivation theory suggests that there is a significant relationship between the influence of product placement with brand awareness.
\end{abstract}

Keywords: Product Placement, Film, Brand Awareness.

\begin{abstract}
Abstrak
Keputusan masyarakat dalam memilih brand didukung dari faktor brand awareness-nya, kesadaran masyarakat terhadap merek didorong oleh adanya stimulus yang dilakukan oleh produsen sehingga membuat konsumen tertarik pada produk tersebut. Film dianggap bisa menjadi wadah untuk para produsen untuk memberikan stimulus serta memasarkan dan mengenalkan produknya. Menggunakan product placement produsen memasarkan suatu brand yang diselipkan dalam sebuah karya film. Intensitas terpaan tayangan product placement ke penonton dianggap dapat mempengaruhi tingkat brand awareness suatu produk, sehingga hal ini dapat meningkatkan citra dari suatu merek produk dan secara langsung dapat meningkatkan daya jual dari produk tersebut. Tujuan dari penelitian ini adalah untuk mengetahui pengaruh terpaan product placement dalam film terhadap brand awareness suatu produk. Metode penelitian yang digunakan adalah studi eksperimen kuantitatif. Populasi dari penelitian ini adalah remaja dari kalangan mahasiswa Ilmu Komunikasi Universitas Muhammadiyah Surakarta. Hasil korelasi data penelitian dengan teori kultivasi menunjukkan bahwa terdapat pengaruh hubungan yang signifikan antara product placement dengan brand awareness.
\end{abstract}

Kata Kunci: Product Placement, Film, Brand Awareness. 
Website: https://ojs.unikom.ac.id/index.php/common

DOI Jurnal: https://doi.org/10.34010/common

DOI Artikel: https://doi.org/10.34010/common.v3i2.1685

\section{Pendahuluan}

Indonesia sebagai salah satu negara berkembang, telah menjadi sasaran produsen untuk memperkenalkan atau memasarkan produk dari suatu merek. Tingkat konsumerisasi masyarakat Indonesia yang tinggi dalam mengkonsumsi suatu produk di pengaruhi oleh faktor kekuatan dari brand itu sendiri, ditunjukkan dari brand awareness suatu produk. Brand awareness berperan dalam mempengaruhi pertimbangan keputusan pembelian oleh konsumen (Suciningtyas, 2012). Minat beli akan timbul apabila konsumen tertarik pada produk yang di tawarkan, kemudian akan mendorong konsumen untuk memberikan keputusan dalam pembelian (Eriza, 2017). Maka produsen memberikan upaya berupa penggambaran pengalaman supaya konsumen dapat terpengaruh dan tertarik oleh brand tertentu. Media massa merupakan wadah yang digunakan untuk melakukan aktivitas komunikasi pemasaran. Televisi sebagai salah satu media yang digunakan untuk melakukan aktivitas pemasaran dan pengenalan produk oleh konsumen, tetapi menurut Kotler (2009) televisi sudah tidak lagi efektif karena semakin tidak karuannya isi iklan di televisi serta beragamnya program acara di televisi.

Survey yang dilakukan oleh salah satu perusahaan pemasaran dan periklanan Indonesia, yakni LOWE Indonesia menyatakan bahwa kurang lebih 53\% penonton televisi memilih mengganti saluran televisi mereka ketika memasuki jeda iklan (Tempo, 2005). Fakta tersebut mendorong produsen menjadi kreatif dalam memilih media periklanan. Film dianggap dapat menyampaikan pesan secara lebih kompleks melalui sajian gambar dan suara, sehingga produsen memberi stimulus berupa penggambaran pengalaman mengenai produk dari suatu brand dalam selipan adegan penceritaan dalam film. Kegiatan penempatan produk dengan menampilkan produk atau merek secara verbal maupun visual dilakukan oleh produsen dengan bekerjasama dan melakukan pembayaran pada sebuah program hiburan di media (Russel, 2002).

Strategi pemasaran produk melaui product placement diharapkan mampu mengatasi kecenderungan atas kejenuhan dan ketidakefektifan terhadap iklan di media massa televisi oleh penonton, karena product placement melakukan kegiatan promosi hanya dengan menempatkan produk sebagai barang atau property dalam film. Seperti penelitian yang dilakukan Artur Cholinski dalam "The Effectiveness of Product Placement: A Field Quasi-Experiment", menyimpulkan bahwa product placement dalam plot film dapat meningkatkan kesadaran merek oleh penonton (Cholinski, 2012).

Menurut Aaker Durianto et al (2004) terdapat beberapa dimensi untuk mengukur brand awareness, yaitu unware of brand, brand recognition, brand recall dan top of mind. Moonhee Yang dan David R. RoskosEwoldsen dalam penelitiannya "The Effectiveness of Brand Placement in the Movies: Levels of Placements, Explicit and Implicit Memory and Brand-Choice Behavior", menyatakan bahwa penempatan produk dalam film terjadi pada berbagai tingkatan yang berbeda dari latar belakang yang sederhana hingga pada bagian yang instrumental dari cerita, dan hal ini mempengaruhi perilaku dan sikap penonton terhadap pemilihan suatu brand (Yang \& Ewoldsen, 2007).

Penelitian lain mengenai pengaruh penempatan produk dalam film terhadap brand awareness oleh penontonnya juga dilakukan oleh Tapan K. Panda dalam penelitiannya yang berjudul "The Effectiveness of Product Placement in Indian Films and Its Effect on Brand Memory and Attitude with Special Referenceto Hindi Films" dapat disimpulkan bahwa penonton secara umum menunjukkan sikap positif terhadap adanya product placement dalam film, namun respon penonton mengenai penempatan produk secara eksplisit memiliki hasil yang lebih baik dibandingkan dengan penempatan produk secara implisit (Panda, 2004). 
Website: https://ojs.unikom.ac.id/index.php/common

DOI Jurnal: https://doi.org/10.34010/common

DOI Artikel: https://doi.org/10.34010/common.v3i2.1685

Penelitian terdahulu mengenai product placement dalam film terhadap brand awareness juga dilakukan oleh (Rumambi \& Krishnasari, 2012), (Primalia, 2013) dan (Kumalasari, 2013). Hasil dari penelitian terdahulu tersebut menyatakan bahwa terdapat korelasi pengaruh positif yang signifikan dalam penggunaan strategi penempatan produk dalam penceritaan film terhadap tingkat brand awareness suatu produk bagi penontonnya. Khalayak mendapatkan terpaan penempatan produk dalam film secara tidak langsung dan dapat memberikan pengaruh yang dapat merubah persepsi audiens mengenai brand awareness dari suatu produk yang ditawarkan dalam film.

Salah satu film Indonesia karya penulis sekaligus influencer muda Raditya Dika telah berhasil menerapkan strategi product placement di dalam filmnya. Film yang berjudul "Cinta Brontosaurus" yang diangkat dari novel ciptaan Raditya Dika ini telah memasukkan unsur penempatan produk dari suatu brand di dalam plot penceritaan film. Pencapaian film "Cinta Brontosaurus" ini sangat positif, dikutip dari kapanlagi.com tercatat bahwa dalam dua hari pertama penayangan, film ini telah tembus ditonton oleh 150.000 penonton (Putra, 2013).

Film "Cinta Brontosaurus" ini rata-rata ditonton oleh para remaja, hal ini dikarenakan Raditya Dika atau penulis film sekaligus pemeran dari film ini adalah merupakan seorang influencer muda yang sedang naik daun dan banyak di kenal di kalangan anak muda karena karya tulisannya di blog pribadi dan novelnya mengisahkan tentang cerita-cerita kaum remaja saat ini. Namun produk yang paling dominan dalam film ini adalah brand "Mie Sedaap Cup", hal ini dikarenakan Raditya Dika juga merupakan brand ambassador dari produk Mie Sedaap Cup. Walaupun tampil hanya beberapa menit dalam tayangan film Cinta Brontosaurus, produk Mie Sedaap Cup menggunakan dimensi-dimensi penempatan produk, yaitu dimensi visual atau screen placement dan plot connection.
Pertimbangan peneliti dalam pemilihan objek produk Mie Sedaap Cup dalam film Cinta Brontosaurus karena melihat mie instan menjadi makanan favorit yang dikonsumsi oleh masyarakat di seluruh dunia. World Instant Noodles Asosiation dalam data demografi menunjukkan bahwa pada tahun 2017 konsumsi mie instan di seluruh dunia mencapai 100 miliar bungkus, naik 2,7\% dari tahun sebelumnya, dikutip dari kompas.com Indonesia menjadi negara dengan konsumen mie instan terbesar kedua di dunia dengan jumlah konsumsi mie instan hingga mencapai 12,62 miliar. Mie instan sudah menjadi makanan pengganti dari makanan pokok bagi sebagian besar penduduk dunia, alasannya karena kemudahan dalam penyajian, rasa yang pasti dan harga yang murah (Nurfadilah, 2018).

Mie Sedaap merupakan produk dari PT Wingsfood yang sudah hadir sejak 2003 dan telah memiliki konsumen tetap terutama dari kalangan remaja, Mie Sedaap memang lebih menyasar kepada masyarakat kalangan menengah kebawah yang menyukai produk instan. Mie Sedaap merupakan mie instan pertama yang telah meraih penghargaan sertifikat ISO 22000 Management System (Standarisasi jaminan terhadap makanan atau food safety) dan Wingscorp merupakan perusahaan manufaktur pertama di Indonesia yang berhasil mendapatkan pengakuan Internasional (www.wingscorp.com, 2019).

Penelitian ini mengacu pada teori kulltivasi atau cultivation theory. Penggunaan teori tersebut dipilih oleh peneliti karena teori kultivasi merupakan teori sosial dari konsep komunikasi massa yang meneliti mengenai efek jangka panjang dari pengaruh tayangan media pada perubahan pemikiran khalayak (Jennings, 2002). Penelitian ini bertujuan untuk mengetahui seberapa berpengaruhkah strategi product placement dalam sebuah film terhadap brand awareness Mie Sedaap Cup bagi sasaran konsumennya. Maka peneliti ingin mengetahui Bagaimana pengaruh product placement terhadap brand awareness Mie Sedaap Cup 
Website: https://ojs.unikom.ac.id/index.php/common

DOI Jurnal: https://doi.org/10.34010/common

DOI Artikel: https://doi.org/10.34010/common.v3i2.1685

dalam film Cinta Brontosaurus di kalangan remaja Surakarta?

\section{Kajian Pustaka dan Kerangka Pemikiran}

Asumsi yang mendasar mengenai teori kultivasi dikemukakan oleh George Gerbner yang menyatakan bahwa terpaan media secara simultan akan memberikan gambaran dan pengaruh pada persepsi pemirsanya (Morissan, 2014). Teori kultivasi ini digunakan karena fungsi iklan di media telah banyak menyajikan bentuk dan gambaran produk dengan realitas sosial di masyarakat, berupa gambar maupun video yang bertujuan untuk mendoktrin atau membentuk konsep persepsi atau pemikiran penontonnya dalam melihat tayangan iklan di media. Pengaruh-pengaruh iklan di media yang berlangsung secara terus menerus, telah membentuk persepsi individu dari audiens dalam memahami realitas sosial yang ingin di tampilkan oleh si pembuat iklan bagi masyarakat (Nurudin, 2007). Pada penelitian terdahulu yang dilakukan oleh Williams et al. (2016) mengenai bagaimana pengaruh penempatan produk di film dalam mempengaruhi perilaku konsumsi audiensnya, didapatkan hasil bahwa melalui pengujian teori kultivasi, semakin lama waktu tayangan, maka akan semakin besar pula kemungkinan mereka terpengaruh dan kemudian mengembangkan pandangan yang sama seperti yang disaksikan audiens dalam film. Selain untuk mengetahui mengenai sebab akibat dari pembentukan persepsi audiens mengenai pesan-pesan di media, teori kultivasi ini juga sering digunakan untuk mengetahui efek iklan yang dibuat media terhadap perubahan perilaku konsumen, seperti yang dilakukan oleh Widiyati di tahun 2011 dengan judul ' Terpaan Iklan Pond's dan perilaku konsumen (Studi Analisis Terpaan Iklan Pond's White Beauty versi dan Alexa Pada Media Televisi Terhadap penerimaan produk di kalangan Mahasiswi FKI UMS)'. Tidak hanya dilakukan melalui televisi, cultivation theory ini juga digunakan pada penelitian mengenai terpaan iklan pada media lain yang bertujuan untuk meningatkan brand equity suatu produk, seperti penelitian yang dilakukan oleh Berry dengan judul Cultivating Service Brand Equity pada tahun 2000.

Kultivasi merupakan proses yang terjadi akibat adanya pengaruh terpaan dari pengirim pesan terhadap penerima pesan dengan menyajikan gambaran pesan dengan realitas dalam jangka waktu atau frekuensi tertentu atau dalam kondisi berulang atau terus menerus sehingga dapat mendorong stimulus atau mendominasi persepsi dari penerima pesan untuk melakukan perubahan pemikiran sehingga penonton atau audiens dapat terdorong untuk melakukan hal yang sesuai dengan yang digambarkan dalam pesan yang disampaikan oleh pengirim pesan.

Product placement adalah suatu strategi penempatan produk bermerek berupa kemasan atau barang dalam sebuah film ataupun media digital lainnya. Menurut Belch dan Belch (2007), product placement adalah sebuah cara untuk meningkatkan promosi sebuah produk atau jasa dengan menampilkan produknya dengan kesan bahwa keberadaan produk tersebut seolah-olah menjadi bagian dari cerita film. Meningkatnya strategi penempatan produk mengindikasikan bahwa pengiklan menggunakan teknik ini untuk mempengaruhi perilaku konsumen terhadap brand yang di pasarkan.

Penempatan produk merupakan kegiatan memperlihatkan atau menampilkan merek brand secara verbal maupun visual yang diselipkan dalam bagian cerita didalam film (Ducan, 2008). Konsep tentang product placement sudah digunakan dalam penelitian terdahulu, seperti yang dilakukan oleh Primalia tahun 2013 yang berjudul 'Representasi Product Placement Dalam Film Habibie dan Ainun' yang menyatakan bahwa visualisasi produk dalam scene dapat memberikan pengaruh yang berbeda pada positioning product oleh konsumen. Penelitian yang berjudul The Effectiveness of Product Placement: A Field Quasi-Experiment yang 
dilakukan oleh Cholinski (2012), menunjukkan bahwa penempatan produk yang dihubungkan dengan audio visual film dapat menghasilkan plot penceritaan yang secara tidak langsung dapat membangun persepsi penonton mengenai produk yang ditampilkan dalam film. Russel (2002) mengkategorikan penempatan produk ke dalam tiga dimensi penempatan produk, yakni sebagai berikut:

a. Penempatan produk secara visual atau screen placement, yakni merupakan dimensi yang merujuk pada tampilan atau bentuk dari merek produk di dalam tayangan penceritaan film.

b. Auditory atau script placement merupakan dimensi product placement dengan melakukan penyebutan produk merek secara lisan oleh pemain dalam tayangan film.

c. Plot connection merupakan dimensi penempatan produk yang merujuk pada keterkaitan merek dengan alur penceritaan dan adegan pada film yang dapat membangun kecinambungan penceritaan dan adegan dalam film.

Strategi penempatan produk ini sangat memperhatikan faktor ketertarikan audiensnya, karena strategi ini dianggap sebagai alternatif atau media untuk memberi kecenderungan pada audiens agar dapat menerima terpaan promosi merek dari suatu produk. Maka dari itu banyak penempatan brand yang dilibatkan dalam proyek pembuatan film untuk tujuan komunikasi pemasaran.

Brand awareness atau kesadaran merek merupakan kemampuan konsumen dalam mengenali atau mengingat merek melalui pesan yang ditangkap oleh konsumen pada saat kemunculan produk dari identitas produknya seperti nama merek, logo, slogan, bentuk kemasan dan sebagainya (Ducan, 2008). Brahmana dkk. (2016) dalam penelitiannya mengenai konsep kesadaran merek berjudul 'Pengaruh Product Placement Pada Film Indonesia Terhadap Brand Awareness dan Purchase Intention Masyarakat Surabaya' menyatakan bahwa semakin tinggi kesadaran merek oleh konsumen dalam hal mengenal dan mengingat akan suatu merek maka juga akan semakin menunjukkan pengaruh positif pada niat beli konsumennya.

Brand awareness merupakan hal yang penting dalam mempengaruhi niat beli konsumen, tujuan dari kesadaran merek adalah untuk membedakan suatu produk atau brand dengan produk lainnya. Sehingga suatu produk dapat memiliki nilai yang nantinya dapat menjadi pertimbangan konsumen ketika akan melakukan proses pembelian suatu produk (Suciningtyas, 2012). Kemampuan konsumen dalam mengukur kesadaran merek di lihat dari tingkatan pengukuran brand awareness menurut Aaker (1996) berikut ini:

a. Top of Mind adalah merek yang pertama kali di ingat dan paling di ingat oleh konsumen.

b. Brand Recall adalah pengingat kembali terhadap merek.

c. Brand Recognition adalah pengenalan merek dimana tingkat kesadaran merek oleh konsumen masih sangat rendah, masih perlu di bantu dengan menyebutkan ciriciri produk untuk mengingat produk.

d. Unware of Brand yaitu tingkatan paling rendah karena dalam piramida kesadaran merek terletak di bagian paling bawah, dimana konsumen tidak atau belum menyadari adanya suatu merek.

Penelitian ini menggunakan metode pengukuran yang sama dengan Aaker, yakni menggunakan 4 pengukuran indikator sebagai aspek pengukuran kesadaran merek. Indikator tersebut adalah Top of mind, Brand recall, Brand recognition dan Unware of brand untuk mengetahui seberapa tinggi tingkat kesadaran konsumen terhadap produk.

\section{Metode Penelitian}

Penelitian ini menggunakan metode eksperimen, yaitu periset meneliti hubungan atau sebab akibat antar variabel dengan melakukan manipulasi satu atau lebih variabel pada suatu kelompok eksperimen dan 
melakukan pembandingan terhadap hasil yang diperoleh. Jenis penelitian ini adalah eksplanatif kuantitatif yang bertujuan untuk mencari hubungan sebab akibat antara dua variabel atau lebih. Penelitian ini bersifat obyektif, sehingga peneliti harus memisahkan diri dari data yang di olah, hasil data harus di uji terlebih dahulu dengan batasan konsep dan alat ukurnya agar memenuhi prinsip validitas dan reliabilitas penelitian. Pembatasan konsepnya adalah dengan cara mengarahkan penelitian dalam seting yang terkontrol, lebih sistematik dan terstruktur dalam satu desain penelitian (Kriyantono, 2010). Metode yang digunakan adalah metode pre-experimental design, dengan desain metode eksperimen one group pretest and posttest design.

Metode pengumpulan data merupakan cara-cara yang digunakan periset untuk mengumpulkan data. Sedangkan dalam penelitian kuantitatif dikenal metode pengumpulan data seperti; kuesioner (angket), wawancara (biasanya berstruktur), dan dokumentasi (Sugiyono, 2008). Pada penelitian ini peneliti menggunakan angket atau kuesioner. Instrumen penelitian dengan kuesioner survei dirancang untuk mengukur pengaruh dari terpaan product placement Mie Sedaap Cup pada responden yang menonton film Cinta Brontosaurus, terhadap brand awareness produk. Metode ini memungkinkan peneliti dalam melakukan pengumpulan data dengan cara mengembangkan kuesioner yang nantinya akan di isi oleh responden. Pendekatan kuantitatif dengan metode survei dipilih karena mampu mengetahui respon masyarakat melalui data yang diperoleh dari responden.

Populasi dari penelitian ini adalah remaja dari kalangan Mahasiswa Ilmu Komunikasi Universitas Muhammadiyah surakarta (UMS). Berdasarkan dari data kemahasiswaan, populasi mahasiswa Ilmu Komunikasi UMS berjumlah 1304 mahasiswa. Teknik sampling penelitian adalah menggunakan purposive sampling dengan memilih secara sengaja menyesuaikan dengan tujuan dari penelitian. Kriteria dari sampel dalam penelitian ini diantaranya, Mahasiswa Ilmu Komunikasi Universitas Muhammadiyah Surakarta, berusia 18-25 tahun, dan berdomisili di Surakarta. Alasan peneliti memilih mahasiswa Ilmu Komunikasi UMS dikarenakan mahasiswa Ilmu Komunikasi juga mendapatkan teori materi perkuliahan mengenai film atau sinematografi dan materi periklanan, selain itu pemilihan responden juga dikarenakan Film Cinta Brontosaurus merupakan film yang ditujukkan untuk kalangan remaja, yakni penonton berusia diatas 13 tahun. Maka peneliti menghitung sampel dari jumlah tersebut dengan menggunakan rumus slovin dan dengan batas kesalahan yang ditolerir sebesar 10\%. Rumus Slovin:

$$
n=\frac{N}{1+N e^{2}}
$$

Dimana :

$\mathbf{N}$ : Jumlah populasi

n : Jumlah sampel

e : Nilai presisi 0,1 (presisi diambil $10 \%$

karena melihat jumlah populasi besar, yakni lebih dari 100)

$n=\frac{1304}{1+130(0,1)^{2}}=92$

Dengan menggunakan rumus slovin tersebut, peneliti menemukan jumlah sampel sebesar 92 orang yang akan dibulatkan menjadi 100. Sehingga, peneliti menyebarkan kuesioner sebagai alat pengumpulan data penelitian kepada 100 orang Mahasiswa Ilmu Komunikasi UMS yang dijadikan sampel penelitian. Sampel merupakan bagian dari populasi yang akan menjadi responden peneliti untuk menjawab pertanyaan maupun mengisi pernyataan di kuesioner. Pengambilan sampel ini dilakukan untuk mewakili seluruh jumlah populasi sebagai responden penelitian.

Peneliti menggunakan kuesioner skala linkert sebagai instrumen pengumpulan datanya. Kuesioner dengan skala linkert digunakan untuk mengukur sikap, persepsi ataupun pendapat dari sekelompok orang tentang fenomena sosial di masyarakat. Peneliti 
Website: https://ojs.unikom.ac.id/index.php/common

DOI Jurnal: https://doi.org/10.34010/common

DOI Artikel: https://doi.org/10.34010/common.v3i2.1685

menggunakan kuesioner skala linkert modifikasi yaitu kuesioner skala linkert modifikasi empat skala, yang berisi pertayaan atau pernyataan serta jawaban berupa dukungan pemikiran atau sikap yang diungkapkan dengan kata-kata, yaitu Sangat Setuju (SS), Setuju (S), Tidak Setuju (TS) dan Sangat Tidak Setuju (STS). Modifikasi skala linkert empat skala ini dimaksudkan untuk mengatasi kelemahan dari skala linkert dlima skala yaitu dengan menghilangkan pilihan jawaban atas keraguraguan yang dapat menimbulkan artian ganda (Hadi, 1999). Kuesioner disebarkan kepada responden penelitian sebelum dan sesudah menonton tayangan film dari objek penelitian yaitu potongan tayangan dari film "Cinta Brontosaurus" dan peneliti juga melakukan komunikasi secara langsung kepada responden untuk mengatasi masalah apabila responden mengalami kesulitan dalam mengisi kuesioner serta untuk membantu memberikan pengarahan dengan menjelaskan tata cara pengisian mengenai kuesioner penelitian tersebut.

Peneliti menggunakan metode eksperimen dengan desain one group pratest and posttest, dimana peneliti hanya menggunakan satu kelompok eksperimen saja tanpa pembanding. Penelitian dengan metode eksperimen dengan desain one group pratest and posttest ini nantinya akan memberikan dua kali pengujian dengan kuesioner dan memberikan suatu perlakuan eksperimen kepada responden. Metode eksperimen one group pratest and posttest design, diharapkan dapat memberikan hasil yang akurat baru penelitian ini. Setelah data diperoleh peneliti melakukan analisis data menggunakan aplikasi Statistic Product and Service Solution (SPSS) Windows versi 25.0.

Tabel 1. Metode Eksperimen One Group Pratest and Posttest Design

\begin{tabular}{c|c|c} 
Pretest & Perlakuan & Posttest \\
\hline $\mathrm{O}_{1}$ & $\mathrm{X}$ & $\mathrm{O}_{2}$
\end{tabular}

Keterangan:

$\mathrm{O}_{1}=$ Skor Pretest

$\mathrm{O}_{2}=$ Skor Posttest
$\mathrm{X}=$ Perlakuan yang berupa memberikan tayangan dari product placement di film"Cinta Brontosaurus"

Agar mendapatkan data penelitian yang sesuai maka kuesioner harus dapat mengukur apa yang harus di ukur dari data. Uji validitas yang digunakan oleh peneliti untuk mengukur hubungan atau nilai keseluruhan dari item pernyataan kuesioner adalah menggunakan metode product moment pearson. Sedangkan untuk uji reliabilitas menggunakan Crocbach's Alpha, untuk mengetahui sejauh mana konsistensi pengukuran dalam memberikan hasil yang serupa jika dilakukan pengukuran kembali. Teknik analisis yang digunakan untuk menguji hipotesis dari pengaruh antara variabel independen dengan variabel dependen adalah menggunakan Uji Paired Sample T-Test (Kriyantonno, 2010). Pengujian dilakukan untuk mengetahui pengaruh dari terpaan penempatan produk terhadap kesadaran merek.

\section{Hasil dan Pembahasan}

Tahapan ini menyajikan data hasil dari penyebaran kuesioner yang sudah diisi oleh responden yakni mahasiswa Ilmu Komunikasi UMS tentang pengaruh terpaan product placement terhadap brand awareness "Mie Sedaap Cup" pada film "Cinta Brontosaurus" di kalangan remaja Surakarta. Stelah data diperoleh selanjtnya peneliti menganalisis dat tersebut menggunakan aplikasi Statistic Product and Service Solution (SPSS) dan ditampilkan dalam bentuk tabel distribusi frekuensi. Tujuan dari tabel distribusi tersebut adalah agar data dapat disajikan secara lebih informatif serta hasil yang diperoleh dari olahan SPSS mudah difahami oleh pembaca.

Dalam sub bab dibawah ini akan dijelaskan hasil dari deskripsi perhitungan data mengenai jawaban responden, pengujian pernyataan analisis berupa uji validitas dan reliabilitas dari hasil kuesioner, analisis data dilakukan sesuai dengan aspek yang diteliti, 
serta pembahasan hasil dari analisis data yang diperoleh.

\subsection{Deskripsi Data}

Deskripsi data adalah tahap dimana peneliti memahami dan mengolah data sehingga hasil data olahan yang ditampilkan mudah dipahami oleh pembaca. Populasi pada penelitian ini berjumlah 1304 orang yang merupakan mahasiswa ilmu komunikasi UMS. Dari jumlah populasi tersebut metode pengambilan sampelnya adalah purposive sampling dimana sampel dipilih berdasarkan karakteristik atau kriteria yang telah ditentukan oleh peneliti, yaitu mahasiswa ilmu komunikasi UMS berusia antara 18-25 tahun yang berdomisili di Surakarta dan dihitung menggunakan rumus slovin dengan batas kesalahan (error) sebesar 10\%.

Dari data yang telah diperoleh ditemukan responden yang sesuai dengan karakteristik yang telah ditetapkan sebelumnya yakni dibagi berdasarkan rentang usia. Kemudian peneliti mengelompokkan responden menjadi 2 kategori yaitu masa remaja awal yaitu rentang usia 18 hingga 21 tahun serta remaja akhir 22 hingga 25 tahun, pembagian rentang usia dihitung dari penggolongan lama masa kuliah.

\subsection{Pengujian Persyaratan Analisis \\ 4.2.1. Uji Validitas}

Uji validitas digunakan untuk mengetahui sejauh mana kecermatan kuesioner menjadi alat ukur untuk mengukur data hasil pada penelitian (Azwar, 1986). Rumus yang digunakan untuk uji validitas adalah Product Moment Pearson, yaitu dilakukan dengan cara menghitung korelasi dari masing-masing skor item pernyataan pada tiap variabel dengan total skor variabel tersebut. Apabila skor berkorelasi postif dengan skor total dan lebih tinggi dari korelasi antar item instrumen tersebut maka dinyatakan valid. Uji validitas dilakukan menggunakan SPSS Windows 25.0. Pada Penelitian ini peneliti menggunakan 100 responden, maka dengan taraf signifikansi 5\% di dapatkan $r$ tabel adalah 0,197. Nilai hitng harus lebih besar dari pada $r$ tabel ( $r$ hitung $>r$ tabel), sehingga dapat dikatakan valid.

Tabel 2. Uji Validitas

\begin{tabular}{|c|c|c|c|}
\hline & Pernyataan & $\mathbf{r}_{\text {hitung }}$ & Valid \\
\hline \multirow{14}{*}{$\mathrm{x}$} & Item 1 & 0,633 & Valid \\
\hline & Item 2 & 0,360 & Valid \\
\hline & Item 3 & 0,922 & Valid \\
\hline & Item 4 & 0,454 & Valid \\
\hline & Item 5 & 0,342 & Valid \\
\hline & Item 6 & 0,199 & Valid \\
\hline & Item 7 & 0,480 & Valid \\
\hline & Item 8 & 0,315 & Valid \\
\hline & Item 9 & 0,402 & Valid \\
\hline & Item 10 & 0,364 & Valid \\
\hline & Item 11 & 0,330 & Valid \\
\hline & Item 12 & 0,747 & Valid \\
\hline & Item 13 & 0,376 & Valid \\
\hline & Item 14 & 0,641 & Valid \\
\hline \multirow{16}{*}{$y$} & Item 1 & 0,480 & Valid \\
\hline & Item 2 & 0,257 & Valid \\
\hline & Item 3 & 0,430 & Valid \\
\hline & Item 4 & 0,653 & Valid \\
\hline & Item 5 & 0,203 & Valid \\
\hline & Item 6 & 0,327 & Valid \\
\hline & Item 7 & 0,344 & Valid \\
\hline & Item 8 & 0,665 & Valid \\
\hline & Item 9 & 0,200 & Valid \\
\hline & Item 10 & 0,426 & Valid \\
\hline & Item 11 & 0,524 & Valid \\
\hline & Item 12 & 1,000 & Valid \\
\hline & Item 13 & 0,407 & Valid \\
\hline & Item 14 & 0,253 & Valid \\
\hline & Item 15 & 0,204 & Valid \\
\hline & Item 16 & 0,497 & Valid \\
\hline
\end{tabular}

Dapat dilihat bahwa dari keseluruhan pertanyaan dan pernyataan maka dapat disimpulkan bahwa kuesioner untuk pernyataan penelitian variable (x) mengenai pengaruh terpaan product placement dalam film "Cinta Brontosaurus" dikatakan valid karena nilai $\mathrm{r}$ hitung lebih besar dari 0,197. Sedangkan pada keseluruhan item pada variabel (y) mengenai brand awareness di daari "Mie Sedaap Cup" juga dinyatakan valid karena nilai $r$ hitung lebih besar dari $r$ tabel yaitu 0, 197. Sehingga dapat 
disimpulkan bahwa masing-masing item memiliki tingkat validitas yang lebih besar dari $\mathrm{r}$ tabel, maka dapat disimpulkan bahwa alat ukur yang digunakan valid untuk digunakan pada penelitian.

\subsubsection{Uji Reliabilitas}

Uji reliabilitas juga dilakukan untuk menguji kebenaran konsistensi pada kuesioner variabel penelitian yang dianggap valid tersebut. Uji reliabilitas juga di uji menggunakan aplikasi SPSS Windows versi 25.0 dengan metode Cronbach's Alpha. Instrumen penelitian dapat dikatakan konsisten atau reliable apabila nilai uji koofisiensi lebih besar dari 0,60. Berikut adalah hasil dari kuesioner mengenai pengaruh terpaan product placement terhadap brand awareness, dimana pada variabel $(\mathrm{x})$ terdapat 14 item pernyataan dan pada variabel (y) terdapat 16 item pernyataan.

Tabel 3. Hasil Pengolahan Data Uji Reliabilitas

\begin{tabular}{|c|c|c|c|c|}
\hline & $\begin{array}{l}\mathrm{N} \text { of } \\
\text { Item }\end{array}$ & $\begin{array}{c}\text { Cronbach's } \\
\text { Alpha }\end{array}$ & $\begin{array}{l}\text { Koofisiensi } \\
\text { Reliabilitas }\end{array}$ & Kesimpulan \\
\hline$x$ & 14 & 0,776 & \multirow{2}{*}{$>0,60$} & Reliabel \\
\hline$y$ & 16 & 0,760 & & Reliabel \\
\hline
\end{tabular}

Dari tabel pengujian koofisensi menggunakan Cronbach's Alpha dapat disimpulkan bahwa pernyataan dari variabel independen dan dependen pada kuesioner dinyatakan reliabel kerena nilai signifikansi yang di dapat lebih besar dari 0,60.

\subsection{Analisis Data}

Data yang didapatkan dari hasil eksperimen adalah berupa tanggapan responden, yang dikelompokkan dan diolah agar dapat memperoleh skor terhadap aspek yang diukur. Nilai rata-rata skor yang didpatkan dari responden digolongkan dalam empat kategori penilaian yakni; Sangat Tidak Setuju
(STS), Tidak Setuju (TS), Setuju (S) dan Sangat Setuju (SS).

Tabel 4. Rating Skor Jawaban Sesuai Skala Penelitian

\begin{tabular}{|c|c|}
\hline Skor & Kategori \\
\hline 1 & Sangat Tidak Setuju \\
\hline 2 & Tidak Setuju \\
\hline 3 & Setuju \\
\hline 4 & Sangat Setuju \\
\hline
\end{tabular}

Sumber: (Kriyantono, 2010)

Pengujian kuesioner dilakukan sebanyak dua kali, dan hasil pengujian dengan metode eksperimen one design group pretest and postest memberikan hasil skor yang berbeda pada tiap item pernyataan.

Tabel 5. Skor Hasil Uji Eksperimen

\begin{tabular}{|c|c|c|c|}
\hline Variabel (X) & Item & $\begin{array}{c}\text { Prosentase } \\
\text { Skor Pretest }\end{array}$ & $\begin{array}{c}\text { Prosentase } \\
\text { Skor Postest }\end{array}$ \\
\hline \multirow{14}{*}{$\begin{array}{c}\text { Terpaan } \\
\text { Product } \\
\text { Placement }\end{array}$} & 1 & $6,05 \%$ & $6,17 \%$ \\
\hline & 2 & $6,14 \%$ & $6,23 \%$ \\
\hline & 3 & $5,69 \%$ & $5,66 \%$ \\
\hline & 4 & $5,41 \%$ & $5,41 \%$ \\
\hline & 5 & $5,85 \%$ & $5,85 \%$ \\
\hline & 6 & $5,05 \%$ & $5,10 \%$ \\
\hline & 7 & $4,71 \%$ & $4,91 \%$ \\
\hline & 8 & $5,19 \%$ & $5,32 \%$ \\
\hline & 9 & $5,46 \%$ & $5,39 \%$ \\
\hline & 10 & $5,62 \%$ & $5,62 \%$ \\
\hline & 11 & $6,01 \%$ & $6,08 \%$ \\
\hline & 12 & $6,08 \%$ & $6,14 \%$ \\
\hline & 13 & $5,19 \%$ & $5,17 \%$ \\
\hline & 14 & $6,08 \%$ & $6,16 \%$ \\
\hline \multicolumn{2}{|l|}{ Total } & $78,62 \%$ & $79,26 \%$ \\
\hline Variabel (Y) & Item & $\begin{array}{c}\text { Prosentase } \\
\text { Skor Pretest }\end{array}$ & $\begin{array}{c}\text { Prosentase } \\
\text { Skor Postest }\end{array}$ \\
\hline \multirow{4}{*}{ Top Of Mind } & 1 & $5,10 \%$ & $5,17 \%$ \\
\hline & 2 & $5,01 \%$ & $5,06 \%$ \\
\hline & 3 & $5,17 \%$ & $5,20 \%$ \\
\hline & 4 & $4,71 \%$ & $4,90 \%$ \\
\hline \multirow{4}{*}{ Brand Recall } & 5 & $3,75 \%$ & $3,79 \%$ \\
\hline & 6 & $4,28 \%$ & $4,32 \%$ \\
\hline & 7 & $4,93 \%$ & $4,98 \%$ \\
\hline & 8 & $4,26 \%$ & $4,32 \%$ \\
\hline \multirow{2}{*}{$\begin{array}{c}\text { Brand } \\
\text { Recognition }\end{array}$} & 9 & $5,12 \%$ & $5,21 \%$ \\
\hline & 10 & $5,15 \%$ & $5,26 \%$ \\
\hline
\end{tabular}


Website: https://ojs.unikom.ac.id/index.php/common

DOI Jurnal: https://doi.org/10.34010/common

DOI Artikel: https://doi.org/10.34010/common.v3i2.1685

\begin{tabular}{|c|c|c|c|}
\hline \multirow{2}{*}{} & 11 & $3,75 \%$ & $3,90 \%$ \\
\cline { 2 - 4 } & 12 & $4,20 \%$ & $4,26 \%$ \\
\hline \multirow{3}{*}{$\begin{array}{c}\text { Unware of } \\
\text { Brand }\end{array}$} & 13 & $5,12 \%$ & $5,21 \%$ \\
\cline { 2 - 4 } & 14 & $3,95 \%$ & $3,92 \%$ \\
\cline { 2 - 4 } & 15 & $4,39 \%$ & $4,53 \%$ \\
\cline { 2 - 4 } & 16 & $4,68 \%$ & $4,68 \%$ \\
\hline \multicolumn{2}{|c|}{ Total } & $73,64 \%$ & $74,79 \%$ \\
\hline
\end{tabular}

Pada hasil data pengolahan skor pada uji eksperimen yang dilakukan oleh peneliti maka didapatkan hasil bahwa responden telah menyadari adanya product placement dalam film, hal ini ditunjukkan dari total skor item pada variabel terpaan product placement mendapatkan hasil sebesar 78,62\%. Namun hasil dari pengujian eksperimen setelah peneliti memberikan tayangan kepada responden berubah, total skor yang didapatkan peneliti setelah melakukan penayangan film kepada responden naik menjadi $79,26 \%$. Hal ini menunjukkan bahwa terpaan product placement efektif untuk memberi dorongan stimulus kepada audiensnya agar terpengaruh oleh produk.

Pada item variabel kesadaran merek didapatkan hasil bahwa jumlah prosentase skor paling tinggi diantara keempat kategori brand awareness oleh konsumen adalah dari kategori Top of Mind, dimana hasil yang didapatkan adalah 20,33\% dari jumlah total skor terhadap pengujian brand awareness yakni sebesar $74,79 \%$. Maka dapat dinyatakan bahwa sebagian besar audiens remaja yang menjadi responden penelitian menyatakan bahwa produk "Mie Sedaap Cup" telah ada pada posisi atas di benak konsumen. Namun, skor paling tinggi pada pengujian kesadaran merek ini terdapat pada salah satu item pernyataan dari kategori brand recognition yaitu pada item ke10, yang artinya responden telah mengenal produk "Mie Sedaap Cup" dari tayangan iklan.

Jadi dapat diartikan bahwa audiens telah menyadari adanya produk pada penempatan produk di dalam tayangan film, dimana pemberian atau terpaan product placement ini sangat efektif mendorong persepsi dari audiens agar terpengaruh oleh produk. Hasil penelitian juga menyatakan bahwa sebagian besar audiens yang menjadi responden berada pada kategori Top of Mind pada tingkat kesadaran mereknya terhadap brand awareness, hal ini karena fakta bahwa responden memberikan pernyataan bahwa mereka sudah mengenal produk "Mie Sedaap Cup" tersebut dari tayangan iklan.

\subsubsection{Uji Normalitas}

Pada analisis data pengujian pertama, peneliti melakukan uji asumsi klasik dengan melakukan uji normalitas. Uji normalitas diperlukan untuk mengetahui apakah populasi data berdistribusi normal atau tidak sebelum melakukan pengujian terhadap hasil yang diperoleh. Uji normalitas ini di hitung menggunakan aplikasi SPSS Windows 25.0 dengan menggunakan metode Saphiro Wilk. Pengujian ini dilakukan guna mengetahui apakah variabel bebas dan variabel tergantung memiliki hubungan yang signifikan. Pada penelitian ini peneliti melakukan penyebaran kuesioner sebanyak dua kali, yaitu penyebaran pertama dilakukan sebelum pemberian perlakuan pada responden, dan penyebaran kuesioner yang kedua adalah setelah responden diberi perlakuan oleh peneliti. Maka di dapatkan hasil sebagai berikut:

Tabel 6. Hasil Pengolahan Data Uji Normalitas

\begin{tabular}{|c|c|c|}
\hline \multicolumn{3}{|c|}{ Shapiro Wilk } \\
\hline & df & Sig. \\
\hline Pratest & 100 & 0,288 \\
\hline Posttest & 100 & 0,284 \\
\hline
\end{tabular}

Hasil dari pengujian normalitas dengan Saphiro Wilk menyatakan bahwa kedua hasil pengujian berditribusi normal karena skor data lebih besar dari 0,05. Maka hasil perhitungan uji normalitas data tersebut dikatakan berdistribusi normal dan dapat digunakan untuk melakukan pengujian berikutnya.

\subsubsection{Uji Paired Sample T-Test}

Setelah melakukan pengujian hasil data di dapatkan data berdistribusi normal, maka hasil data di lanjutkan dengan melakukan pengujian 
Website: https://ojs.unikom.ac.id/index.php/common

DOI Jurnal: https://doi.org/10.34010/common

DOI Artikel: https://doi.org/10.34010/common.v3i2.1685

Paired Sample T-Test. Analisis paired sample t-test dinyatakan terdapat korelasi atau pengaruh apabila indikasi skor pengujian lebih kecil dari angka 0,05 .

Tabel 7. Hasil Pengolahan Data Uji Paired Sample T-Test

\begin{tabular}{|c|c|c|c|}
\cline { 2 - 3 } \multicolumn{1}{c|}{} & $\mathbf{N}$ & df & $\begin{array}{c}\text { Sig. } \\
\text { (2tailed) }\end{array}$ \\
\hline $\begin{array}{c}\text { Pair 1 pretest } \\
\text { and posttest }\end{array}$ & 100 & 99 & 0,001 \\
\hline
\end{tabular}

Pada pengujian hasil data dari metode eksperimen dengan one group pretest and posttest di dapatkan hasil data yang dihitung menggunakan aplikasi SPSS versi 25.0 dengan metode paired sample t-test bahwa terdapat hubungan yang signifikan antara variabel bebas dan variabel pengaruh. Pada pengujian paired sample t-test apabila di dapatkan hasil signifikansi 2 tailed lebih besar daripada 0,05 maka tidak terdapat perbedaan pada data antara hasil eksperimen uji pretest dan posttest, namun apabila nilai atau skor signifikansi 2 tailed lebih kecil dari 0.05 maka terdapat perbedaan antara hasil pengujian pretest dan posttest pada suatu eksperimen. Maka dari tabel diatas dapat kita simpulkan bahwa terdapat perbedaan pada hasil pengujian pretest dan posttest pada eksperimen penelitian karena skor signifikansi 2 tailed menunjukkan angka sebesar 0,001 yang artinya lebih kecil daripada 0,05 . Sehingga dapat kita simpulkan bahwa terdapat pengaruh positif yang signifikan antara product placement terhadap brand awareness Mie Sedaap Cup pada film Cinta Brontosaurus di kalangan remaja.

\subsection{Pembahasan}

Penelitian ini berfokus pada strategi periklanan pada media film yang digunakan untuk mengkomunikasikan atau menyampaikan pesan dan maksud dari produsen atau pembuat iklan agar sampai pada audiens. Berdasarkan hasil uji validitas, seluruh item pernyataan pengujian mengenai terpaan media terhadap penempatan produk dinyatakan valid. Hasil survey yang dilakukan oleh LOWE perusahaan periklanan di Indonesia mendukung pernyataan bahwa $53 \%$ penonton televisi merasa terganggu oleh adanya jeda iklan (Tempo, 2005). Hal ini menunjukkan bahwa iklan sudah tidak lagi efektif di lakukan pada media televisi. Merambah pada dunia perfilman kini iklan dilakukan dengan cara penempatan produk dalam cerita atau yang sering disebut dengan product placement yang secara sengaja menampilkan merek dari suatu produk ke dalam unsur penceritaan atau adegan film.

Pada penelitian yang dilakukan oleh Rumambi.dkk (2012) dengan judul 'Analisa Efektivitas Product Placement Burger King dalam Film Iron Man 1 dan Audi dalam Film Iron Man 2', menyatakan bahwa Kesadaran responden mengenai kehadiran produk-produk tersebut mencapai $50 \%$ hingga $70 \%$, penonton menyadari kehadiran produk dalam cerita film. Sama halnya dengan penelitian yang dilakukan oleh peneliti mengenai pengaruh terpaan penempatan produk terhadap brand awareness bahwa di dapatkan hasil 79,26\% jawaban responden menyatakan bahwa konsumen menyadari adanya penempatan produk ketika brand di tayangkan dalam adegan atau unsur penceritaan film.

Terpaan penempatan produk memberikan pengaruh pada perilaku konsumennya terutama dalam faktor untuk mempengaruhi niat beli konsumen, hal ini sesuai dengan teori kultivasi yang menyatakan bahwa suatu penggambaran nyata dalam realitas dapat membuat audiens terpengaruh dan terperdaya untuk melakukan perubahan persepsi atau pola pemikirannya. Penelitian yang berjudul Recognition and Recall of Product Placement in Films and Broadcast Programmes yang dilakukan oleh Williams et.al pada tahun 2016 menyatakan bahwa dalam penerimaan pesan menjadi suatu kesadaran merek oleh konsumen juga di dorong oleh adanya proses kultivasi, dimana penonton terpengaruh oleh tayangan merek pada film sehingga menimbulkan rasa atau dorongan 
Website: $\underline{\text { https://ojs.unikom.ac.id/index.php/common }}$

DOI Jurnal: https://doi.org/10.34010/common

DOI Artikel: https://doi.org/10.34010/common.v3i2.1685

pengaruh pada niat beli konsumen. Peneliti dalam penelitian mengenai 'Pengaruh Terpaan Product Placement Terhadap Brand Awareness "Mie Sedaap Cup" pada Film "Cinta Brontosaurus" di kalangan Remaja Surakarta juga menyatakan bahwa proses kultivasi atau penerimaan pengaruh memberikan efek yang positif atau memberikan perubahan yang signifikan pada proses penyampaian pesan dalam iklan, hal ini ditunjukkan dari skor pengujian data dengan analisis paired sample ttest dimana data yang dihasilkan dalam penelitian eksperimen mencapai angka 0,001 yang artinya lebih kecil dari 0,05 yang memberi indikasi adanya perbedaan hasil, maka hasil data penelitian tersebut menunjukkan bahwa adanya penempatan produk di dalam film mampu merubah persepsi penonton terhadap produk.

Kesadaran konsumen akan brand awareness ini juga dibagi dalam empat kategori oleh Aaker (1996) dalam penelitian yang dilakukan oleh Brahmana.dkk, 2016 yang berjudul 'Pengaruh Product Placement pada Film Indonesia terhadap Brand Awareness dan Purchase Intention Masyarakat Surabaya' kategori kesadaran merek yakni, Top of Mind, Brand Recall, Brand Recognition serta Unware of Brand. Setelah dilakukan penelitian dengan menggunakan metode eksperimen one group pretest and posttest dengan pengukuran kategori yang sama dengan penelitian yang dilakukan oleh Brahmana.dkk, 2016 sebelumnya, maka didapatkan hasil bahwa angka $r$ hitung yang paling tinggi didapatkan pada item pernyataan ke 12 pada variabel brand awareness, yakni pada pernyataan bahwa konsumen sudah membeli produk "Mie Sedaap Cup" karena kualitasnya bukan karena faktor lain, hal ini menunjukkan bahwa tingkat kesadaran konsumen akan produk dari Mie Sedaap Cup termasuk pada kategori Brand Recognition. Artinya penonton telah mampu mengidentifikasi merek yang disebutkan. Konsumen mampu mengenai produk namun masih membutuhkan alat bantu untuk mengingat merek tersebut.
Pada hasil data pengolahan skor pada uji eksperimen yang dilakukan oleh peneliti maka didapatkan hasil bahwa responden telah menyadari adanya product placement dalam film, hal ini ditunjukkan dari total skor item pada variabel terpaan product placement mendapatkan hasil sebesar 78,62\%. Namun hasil dari pengujian eksperimen setelah peneliti memberikan tayangan kepada responden berubah, total skor yang didapatkan peneliti setelah melakukan penayangan film kepada responden naik menjadi 79,26\%. Hal ini menunjukkan bahwa terpaan product placement efektif untuk memberi dorongan stimulus kepada audiensnya agar terpengaruh oleh produk.

Pada item variabel kesadaran merek didapatkan hasil bahwa jumlah prosentase skor paling tinggi diantara keempat kategori brand awareness oleh konsumen adalah dari kategori Top of Mind, dimana hasil yang didapatkan adalah 20,33\% dari jumlah total skor terhadap pengujian brand awareness yakni sebesar $74,79 \%$. Maka dapat dinyatakan bahwa sebagian besar audiens remaja yang menjadi responden penelitian menyatakan bahwa produk "Mie Sedaap Cup" telah ada pada posisi atas di benak konsumen. Namun, skor paling tinggi pada pengujian kesadaran merek ini terdapat pada salah satu item pernyataan dari kategori brand recognition yaitu pada item ke10, yang artinya responden telah mengenal produk "Mie Sedaap Cup" dari tayangan iklan.

Pada Kategori brand awareness di dapatkan hasil bahwa dari total $74,79 \%$, sebesar $17,41 \%$ responden kesadaran mereknya termasuk dalam kategori brand recall, artinya audiens mampu mengingat merek tanpa diberi stimulus. Sementara pada 18,63 audiens termasuk dalam kategori brand recognition yang artinya audiens sudah mengenali produk namun masih membutuhkan stimulus ketika dihadapkan pada merek tersebut. Sisa 18, 34\% audiens lainnya adalah tergolong pada kategori audiens dengan kesadaran merek pada tingkat unware of brand, yakni audiens masih merasa ragu dan belum sepenuhnya yakin dalam 
Website: https://ojs.unikom.ac.id/index.php/common

DOI Jurnal: https://doi.org/10.34010/common

DOI Artikel: https://doi.org/10.34010/common.v3i2.1685

mengenal merek, atau bahkan audiens tidak menyadari kehadiran merek pada tayangan film tersebut.

Dimensi penempatan produk yang digunakan produsen untuk produk "Mie Sedaap Cup' ini adalah menggunakan dimensi visual atau screen placement dan juga plot connection dimention yaitu dimensi yang merujuk pada penempatan merek dalam cerita film. Dalam film Cinta Brontosaurus, produk Mie Sedaap Cup ini tampil dalam adegan penceritaan film, produk tayang dengan dimensi visual selama kurang lebih 2 menit yaitu pada detik ke 26:21 sampai 28:18, dimana produk dijadikan properti dalam film. Dalam penceritaan produk diceritakan sebagai makanan alternatif bagi anak muda, yang notabene anak muda lebih suka pada makanan yang instan, mudah, murah dan tidak sulit di dapatkan.

Raditya Dika dan Eriska Reinisa sebagai pemeran aktor dalam film menceritakan pada adegan bahwa mereka sedang ingin keluar makan malam bersama, namun mereka merasa tidak nyaman melakukan pertemuan dan makan malam di restoran Prancis, dan mereka kemudian memilih makan "Mie Sedaap Cup" di tempat yang unik yaitu disuatu tempt diatas atap Pom Bensin, dimana mereka bisa berbincang-bincang dengan bebas. Penempatan produk tidak menggunakan dimensi verbal karena dalam film, pemeran tidak menyebutkan nama merek sama sekali, hanya menampilkan kemasan produk dan menyelipkan produk ke dalam unsur penceritaan.

Keputusan masyarakat dalam memilih suatu brand juga dikarenakan dari faktor brand awareness-nya, kesadaran masyarakat terhadap suatu merek didorong oleh adanya stimulus yang dilakukan oleh produsen kepada calon konsumennya dengan upaya pemberian penggambaran mengenai produk tersebut sehingga nantinya membuat konsumen tertarik pada produk tersebut. Film dianggap bisa menjadi wadah untuk para produsen untuk memberikan stimulus serta memasarkan dan mengenalkan produknya. Menggunakan product placement produsen memasarkan suatu brand yang diselipkan dalam sebuah karya film. Intensitas terpaan tayangan product placement ke penonton dianggap dapat mempengaruhi tingkat brand awareness suatu produk, sehingga hal ini dapat meningkatkan citra dari suatu merek produk dan secara langsung dapat meningkatkan daya jual dari produk tersebut.

Konteks yang berbeda ini menunjukkan bahwa bagaimana suatu merek dimunculkan dalam film dan dapat menimbulkan perasaan cocok pada pemahaman dan penceritaan film. Pada hal ini dapat kita fahami bahwa proses kultivasi dalam mempengaruhi konsumen dengan penempatan produk sangat efektif untuk meningkatkan kesadaran merek produk sehingga dapat meningkatkan nilai dari brand awareness.

\section{Kesimpulan dan Rekomendasi}

Keputusan masyarakat dalam memilih brand juga dikarenakan faktor brand awareness-nya, maka para produsen berupaya memberi pengaruh pada konsumennya melalui strategi iklan di media. Pada hasil data penelitian uji eksperimen menggunakan paired sample t-test didapatkan angka signifikansi 0,001 yang artinya lebih kecil dari 0,05 yang memberi indikasi adanya perbedaan hasil pada pengujian pretest dan posttest yang telah dilakukan. Pada hasil tabulasi data penelitian, didapatkan bahwa kategori Top of Mind mendapatkan jumlah prosentase paling tinggi yakni $20,33 \%$. Namun terdapat fakta bahwa, skor paling tinggi pada pengujian per-item pada kesadaran merek terdapat pada kategori brand recognition yaitu, mengenai pernyataan bahwa responden telah mengenal produk "Mie Sedaap Cup" dari tayangan iklan.

Jadi dapat disimpulkan bahwa proses kultivasi akibat penayangan product placement dalam film efektif untuk mempengaruhi persepsi penonton terhadap produk dan dapat meningkatkan brand awareness. Kejelasan dimensi dalam penempatan produk merupakan faktor yang dapat mempengaruhi penerimaan 
konsumen terhadap kesadaran merek. Hasil analisis data yang diperoleh menunjukkan bahwa sebagian besar responden yang notabene adalah kalangan remaja manyatakan bahwa produk "Mie Sedaap Cup" telah berada pada posisi atas di benak konsumen. Sebagian besar responden juga menyatakan bahwa responden telah mengenal produk "Mie Sedaap Cup" dari tayangan iklan.

Penelitian mengenai product placement ini hanya membahas mengenai pengaruh penempatan produk atau brand yang berupa barang terhadap kesadaran merek. Maka dari itu penelitian selanjutnya diharapkan dapat memilih brand yang juga menawarkan jasa tidak hanya barang, untuk mengetahui efektifitas dan kesadaran merek oleh konsumen, serta melihat sejauhmana brand yang menawarkan jasa tersebut memberikan kepuasan terhadap konsumennya.

\section{Daftar Pustaka}

\section{Buku:}

Azwar Saifudin. 1986. Validitas dan Reliabilitas. Jakarta: Rineka Cipta.

Belch, George E., \& Belch, Michael A. 2007. Advertising and Promotion An Integrated Marketing Communication Perspective. New York: McGraw-Hill, Inc.

Ducan, Tom. (2008). Principle of Advertising and IMC (2). Singapore: Mc Graw Hill.

Durianto, D., Sugiarto, \& Sitinjak, T. 2004. Strategi menaklukan Pasar Melalui Riset Ekuitas dan Perilaku Merek. Jakarta: PT. Gramedia Pustaka Utama.

Hadi, Sutrisno. 1999. "Methodology Research".Yogyakarta: Yayasan Penerbit Fakultas Psikologi Universitas Gajah Mada.

Jennings, Bryant, Dolf, Zilllman. 2002. Media Effects Advances In Theory And
Research. Second Edition. Lawrence Erlbaum Associates, Publisher.

Kriyantono, Rachmad. 2010. Teknik Praktis Riset Komunikasi. Jakarta: Kencana Prenada Group.

Morissan. 2014. Teori Komunikasi: Individu Hingga Massa. Jakarta: Kencana Prenadamedia Group.

Nurudin, M. 2007. Pengantar Komunikasi Massa. Jakarta: PT. Raja Grafindo Persada.

Sugiyono. 2011. Metode Penelitian Kuantitatif Kualitatif dan $R \& D$. Bandung: Alfabeta.

\section{Karya Ilmiah:}

Brahmana, M,R., \& Kristanto, H. 2016. "Pengaruh Product Placement Pada Film Indonesia Terhadap Brand Awarness dan Purchase Intention Masyarakat Surabaya”, dalam Jurnal Manajemen Pemasaran.

Cholinski, Artur. 2012. "The Effectiveness of Product Placement: A Field QuasiExperiment", dalam International Journal of Marketing Studies Vol.4 (5). 14-28.

Eriza, Zahra, Noor. 2017. "Peran Mediasi Citra Merek dan Persepsi Resiko pada Hubungan antar Electronic Word of Mouth (E-WOM) dan Minat Beli (Studi Pada Konsumen Kosmetik E-Commerce di Solo Raya)", dalam Jurnal Komuniti. http://journals.ums.ac.id/index.php/komu niti/article/view/3501/2764.

Kotler, P. 2009. Marketing Management. Alphabet Soup, 15(2). 51-51.

Kumalasari, Puti. (2013). Skripsi "Analisis Pengaruh Brand Awareness dan Brand 
Website: https://ojs.unikom.ac.id/index.php/common DOI Jurnal: https://doi.org/10.34010/common

DOI Artikel: https://doi.org/10.34010/common.v3i2.1685

Image Terhadap Brand Equity dan Dampaknya Pada Minat Beli Konsumen". Fakultas Ekonomika dan Bisnis Universitas Diponegoro.

Panda, T.P. 2004. "Effectiveness of Product Placements in Indian Films and Its Effects on Brand Memory and Attitude with Special Reference to Hindi Films", dalam Journal of Indian Institute of Management Kozhikode.

Primalia, Inneke. 2013. "Representasi Product Placement Dalam Film Habibie dan Ainun”, dalam Jurnal Komunikasi.

Rumambi, Leonid, J, S.E., MM \& Krishnasari, Nike. 2012. "Analisa Efektivitas Product Placement Burger King Dalam Film Iron Man 1 dan Audi dalam Film Iron Man 2", dalam Jurnal Manajemen Pemasaran. Vol. 1(1). 1-10.

Russel, C.A. 2002. "Investigating The Effectiveness of Product Placement in Television Shows: The Role of Modality $\&$ Plot Connection Congruence on Brand Memory Attitude", dalam Journal of Consumer Research, (29), 308.

Suciningtyas, Wulan. 2012. "Pengaruh Brand Awarenes, Brand Image Dan Media Communication Terhadap Keputusan Pembeli", dalam Jurnal Manajemen. Vol. 1. 1-8.

Widiati, Vidia. 2011. Skripsi "Terpaan Iklan Pond's dan Perilaku Konsumen (Studi Analisis Terpaan Iklan Pond's White Beauty Versi Afgan dan Alexa 'Wajahmu Mengalihkan Duniaku' Pada Media Televisi Terhadap Penerimaan Produk di Kalangan Mahasiswi FKI UMS Angkatan 2006-2009)". Fakultas Komunikasi dan Informatika Universitas Muhammadiyah Surakarta.
Williams, S., Walt, D, L \& Preez, Du. 2016. "Recognition and Recall of Product Placement in Films and Broadcast Programmes", dalam Journal Marketing. 19-27.

Yang, Moonhee,. \& Ewoldsen, Roskos. 2007. "The Effectiveness of Brand Placements in the Movies: Level of Placements, Explisit and Implicit Memory, and BrandChoice Behavior", dalam Journal of Communication.

Author. 2019. Mie Sedaap Cup Raih Penghargaan ISO 22000 Management System-www.wingscorp.com. Retrieved September 25, 2018 from https://content/story/www.wingscorp.com

Khairunnisa. 2005. 53 Persen Pemirsa Nilai Iklan Televisi Membosankan www.tempo.com. Retrieved September 12, 2018 from http://www.tempo.co/read/news/2005/03 /03/05657418/53-Persen-Pemirsa-NilaiIklan-Televisi-Membosankan

Nurfadilah, Putri, Syifa. 2018. Mie Instan Jadi Candu Dunia, Indonesia Nomor 2 Pengonsumsi Tertinggiwww.kompas.com. Retrieved January 02, 2019 from http://www.kompas.com/ekonomi/read/2 $\underline{018 / 09 / 25 / 114900426 / m i-i n s t a n-j a d i-}$ candu-dunia-indonesia-nomor-2pengonsumsi-tertinggi

Putra, Mahardi, Eka. (2005). 'Cinta Brontosaurus' Tembus 150.000 Penonton Dalam 2 Hari www.kapanlagi.com. Retrieved January 02, 2019 from http://www.kapanlagi.com/amp/showbiz /film/indonesia/cinta-brontosaurustembus-150000-penonton-dalam-2-haricf648.html 